\title{
The Impact of the Use of Hierarchical Teaching on Test Scores of Students' Technology
}

\author{
Guorong Zhao and Meng Yang \\ North China Electric Power University, 071003 Baoding Hebei, China
}

\begin{abstract}
Test scores of students' technology is the main basis for physical examination of college students' physical, fitness evaluation based on test results. To change the view by the stratified teaching method consistent system of teaching mode, special movement technical level of students is improved significantly.
\end{abstract}

Keywords. layered approach; the technical test; affect

\section{Introduction}

The present college physical educational classes have fixed teaching syllabus and teaching plan, unified class and the teaching goal of student's physical quality and learning ability does not differentiate adopted a consistent type teaching method. Use class teaching, physical education teachers are faced with uneven dozens of physical quality of the students, it is difficult to be treated differently or special treatment only from the "average" of teaching. This has caused students "food" and "eat" situation. Inhibition of the students to develop their expertise and ability, affect the students' learning enthusiasm and interest in learning. Potential cannot fully play and explore students, stimulate students' spontaneous awareness of physical exercise. Sports test results as an important information to judge students' athletic ability and physical quality feedback. How to improve the test scores of student. To solve this problem, according to the analysis of teaching results by using stratified teaching method and expounds its influence on the test scores of students' technology.

\section{The object and method of research}

\subsection{The object of study}

From grade one or two students in my school, in randomly select the classes test scores of two basketball classes and two volleyball classes.

\subsection{The methods of research}

The method of literature: access to relevant information from the Chinese academic periodical net understand research status in stratified teaching method provides a solid theoretical foundation for this research.

The questionnaire survey method: according to the study of students need to design the questionnaire of four sports class questionnaire and recovery of 120 questionnaires, 120 questionnaires were returned the recovery rate is $100 \%$, effective questionnaire 115 , effective rate was $95.8 \%$.

Mathematical statistics: the obtained data by using Excel software for statistics and comparative analysis, comparison of the experimental class and the control class differences in the data on the size and diversity

Interview: the present situation of sports teaching, the students to master the movement skill level, systematic investigation teaching, to develop students' self-evaluation.

\section{The overall analysis}

(1) Through the investigation of scores of the experimental class and the control class analysis (see Table 1.) results using the very obvious in the volleyball teaching course hierarchical teaching method has achieved remarkable results. First pass yield significantly better than the control class students for technical appraisal. While the use of layered teaching in basketball class effect is slightly worse than the volleyball class.

(2) Volleyball is a net sport, basketball has intense physical confrontation. Both games must be completed by mating attack. Two movements are required the team to have good personal technology. But in the course of teaching basketball, running technology more prominent was significantly higher than that of volleyball. Volleyball is more emphasis on stabilizing output technology.

From the course of basketball and volleyball in the course of the project, the application effect of hierarchical 
Table 1. The test of basketball experimental class and the control class.

\begin{tabular}{|c|c|c|c|c|c|c|}
\hline Options & $\begin{array}{l}\text { More than } \\
90 \text { points }\end{array}$ & $\begin{array}{l}\text { More than } \\
80 \text { points }\end{array}$ & $\begin{array}{l}\text { More than } \\
70 \text { points }\end{array}$ & $\begin{array}{l}\text { More than } \\
\text { points }\end{array}$ & $\begin{array}{l}\text { Less than } \\
60 \text { points }\end{array}$ & Total \\
\hline Experimental class & 5people & 15 people & 6 people & 3 people & 1 people & 30 people \\
\hline Control class & 4 people & 12 people & 8 people & 4 people & 2 people & 30 people \\
\hline
\end{tabular}

Table 2. The test of volleyball experimental class and control class.

\begin{tabular}{lllllll}
\hline \multirow{2}{*}{ Options } & More than & More than & More than & More than & $\begin{array}{c}\text { Less than } \\
\text { points }\end{array}$ & 60 points \\
& 90 points & 80 points & 70 points & Total \\
\hline Experimental class & 4people & 16 people & 5 people & 5 people & 0 people & 30 people \\
Control class & 3 people & 10 people & 8 people & 8 people & 1 people & 30 people \\
\hline
\end{tabular}

Table 3. The questionnaire of one-time pass rate of basketball course examinations of experimental class and the control class.

\begin{tabular}{lllllll}
\hline \multirow{2}{*}{ Options } & $\begin{array}{l}\text { Fixed point } \\
\text { free throws }\end{array}$ & $\begin{array}{l}\text { Marching pass } \\
\text { the ball }\end{array}$ & $\begin{array}{l}\text { 30S shot under the } \\
\text { basket }\end{array}$ & $\begin{array}{l}\text { Three for } \\
\text { layup }\end{array}$ & \multirow{2}{*}{ Five CIC } & Linear layup \\
\hline Experimental class & $90 \%$ & $85 \%$ & $95 \%$ & $78 \%$ & $86 \%$ & $92 \%$ \\
Control class & $80 \%$ & $82 \%$ & $70 \%$ & $77 \%$ & $76 \%$ & $87 \%$ \\
\hline
\end{tabular}

Table 4. The questionnaire of one-time pass rate of volleyball course examinations of experimental classes and control classes.

\begin{tabular}{lllllll}
\hline Options & Self-pad ball & $\begin{array}{l}\text { The Autobiography } \\
\text { of the ball }\end{array}$ & Serve & Pick a pass & Mutual batting & Mutual pass \\
\hline Experimental class & $90 \%$ & $91 \%$ & $95 \%$ & $80 \%$ & $86 \%$ & $89 \%$ \\
Control class & $82 \%$ & $81 \%$ & $72 \%$ & $75 \%$ & $76 \%$ & $84 \%$ \\
\hline
\end{tabular}

teaching method in Volleyball Teaching in china. Since the dig, each other mutual autobiography ball, pass the test project, the sports teachers of students according to different athletic ability and physical quality, teach students in accordance with their aptitude, step by step to carry out the teaching work, will receive the obvious teaching effect. Results from table 4 may. The basket, the basket $30 \mathrm{~S}$ shot two test project point penalty basketball class teaching, using the hierarchical teaching method after the effect is obvious. The first pass rate of the experimental class was significantly higher than that of the control class. The percentage distribution of grades can be seen through the examination of the experimental class is significantly higher than the control class. Obviously, the application of teaching method has improved the student test scores.

(3) Analysis of results

A. The students pay attention to whether they can pass the examination accounted for $92 \%$, the other $3 \%$ of the students test scores in the pass of negative attitude. Analysis of the reasons, this part of the students think whether can pass mainly depends on the individual factors of Physical educational teachers.

$B$. On the teachers' teaching attitude survey showed that $95 \%$ of the students to give a high evaluation.

C. As the students asked the control class and experimental class $85 \%$ students, using the same teaching mode will get better exam results.

(4) Investigation and analysis of the results of interviews.

$A$. The majority of the students in PE teaching situation expressed approval. Cause analysis: students think teaching syllabus which is a school established invariant.
$B$. The students master sports skills and test scores are proportional to the level of teaching, could truly reflect their athletic ability.

C. Investigation teaching, teacher absenteeism rate was $0.5 \%$. For teachers' classroom teaching students express approval.

\section{Conclusions}

Through the different levels of teaching, students' basketball technical level has been significantly improved, sports scores improved significantly. The two test project has obvious technique to improve the shooting. No significant differences between the two test project and run basket.

Through the different levels of teaching method of volleyball teaching. The difference of testing index was significantly higher than that of the basketball project. The test items were significantly improving.

Level teaching method using also exists obvious difference in different sports.

Application of different teaching methods significantly improves the quality of PE teaching, have significant difference on student test scores technique.

P.E. teachers have a strong sense of responsibility, serious, dedicated, but also teach students in accordance with their aptitude, study the teaching material, the teaching method flexibly, actively expand the service level, make a contribution to China's sports undertaking.

Sports teaching methods change, the true meaning of student test scores improved technology is not the University of Physical Education. So to deepen the teaching reform and better quality education services, improve student participation in sports enthusiasm, the desire to meet a strong and successful student performance. Im- 
prove the quality of P.E. teaching, and to cultivate lifelong sports consciousness exercise students.

\section{References}

1. Huang, S.J. The practice of hierarchical teaching method in college basketball teaching [J]. Neijiang Science and Technology, 2012, (06).

2. Liu, M. The value of teachers' personality in physical education in quality education [J]. Journal of Hebei Normal University (Natural Science Edition), 2003, 27(5):538-540.
3. Lin, L.P. \& Zhu, L. Review of research on sports teaching style [J]. Sports Science Research, 2006, 10 (3):74-75.

4. Wang, X.D. Analysis and optimization strategy of university sports stratified teaching problems [J]. Shandong Sports Science and Technology, 2012, 6(3):74-77.

5. Luo, X.C. \& Yang, H.W. Study on the misunderstandings and countermeasures existing in the current physical education in Chinese universities [J]. Journal of Shandong Sports Institute, 2008, 24 (5):83-85. 